\title{
AUTHORSHIP IN HISTORICAL PERSPECTIVE AND ITS BEARING ON NEW TESTAMENT AND EARLY CHRISTIAN TEXTS AND CONTEXTS
}

Pieter JJ Botha

New Testament

Unisa

\begin{abstract}
'Authorship' in Greco-Roman times must be understood as an interpretive, cultural construct. Writing activities were collective and participatory, and ranged, depending on the location and period, from courtiership to editorial, translation and facilitation work to entertainment to legal practice to education, embedded in pre-print contexts without the judicial and social institution of copyright. Whatever it was that ancient authors did when they wrote down and diffused thought, 'authorship' in antiquity must not be seen along the lines of modern, romanticist projections of the solitary, brilliant individual.
\end{abstract}

Keywords: Author, Authorship, Literary Activity, Roman Literature, Greco-Roman Background, Book History, Writing, Scribal Culture

\section{Authorship?}

Author and authorship are very common concepts in New Testament (NT) scholarship. Remarkably, little attention is given to question as to what we mean by these terms.

Luke is a student of the LXX. It is clear today that the author of the third Gospel consciously intended to cover his narrative in a 'sacred' mantle. Characteristic of Lk, in this sense, is the frequent use of the introductory formula $k a j$; eg enet $0 \ldots$ which can create a certain sensation of monotony. Mk ... was re-ordered by Lk to introduce his own material into it, but reinforcing it to give the impression of a coherent whole. His style is consciously simple, taking account of the level of his readers and the tone of his sources ... Luke exhibits a certain awareness of style (Piñero \& Peláez 2003:493, my italics).

The italics are used to draw attention to how Piñero and Peláez (a randomly selected example) give contents to their use of the word 'author' in the second sentence of the quotation: note the number of concepts that are clearly open for anachronistic and modernising construction. The typical way that 'author' is used by NT scholars can probably best be characterised by the way Mack describes the origins of the second Gospel: "It was composed at a desk in a scholar's study lined with texts and open to discourse with other intellectuals" (Mack 1988:322-323).

What we find is an underlying understanding of the 'author' as a superior and solitary creative individual (if not genius), often implicitly understood as heroically striving for the 'well-being' of his community; the sovereign author whose intention contains 
the meaning of the work and whose biography authorises, directs and determines its writing. ${ }^{1}$

'Author' is a word easily used, but mostly without historical contextualisation. In this study I offer a brief introduction to the problem, in order to contribute to developing a more adequate model of authorship.

Authorship is first and foremost a problem of culture, and it should be studied as a sociological problem in order to understand it historically. It is necessary to contextualise authorship because writing and reading are culturally embedded phenomena, similar to other social conventions. Furthermore, the historical constraints of ancient text production must be taken into account when we discuss the authors of Greco-Roman texts.

\section{Authorship has a history}

One of the legacies of living with the conceptual construction called 'Enlightenment' is the systematisation of the history of ideas in terms of individual authors' biographies. Modern historiography organised itself, since its inception in the late nineteenth century, as a massive collective biography of writers. This 'man and his work' biographical approach informs the problems, the understanding of sources, the methods and the outcomes of scholarship dealing with literary texts - including biblical scholarship.

However, we need to understand that 'authorship' has a history. Consider the social, political and cultural contexts of authors: our modern, contemporary understanding of the concept is determined by the transformation and decline of European courts and aristocratic patronage, presupposes a large-scale commerce in print and other symbolic goods, and the development of specific, novel forms of associations and modern social institutions. Whereas authorship was, in earlier times, intimately part of patronage it has become, for us, something determined by printing, literary property, censorship and income.

An array of sound scholarship undermines any continuity with regard to models of literacy and authorship between antiquity, the Middle Ages and modern times by exposing the remarkable and important developments in practices of writing and practices of reading. ${ }^{2}$

A useful starting point for a theoretical reflection on these issues is a short essay by Michel Foucault (1971). Foucault asks the question, 'What is an author?', against the background of how Western culture since the Enlightenment uses the concept genius to think about literary and intellectual creation. This emphasis on the singularity of particular individual's creative knowledge should in itself alert us to the problems of anachronistic and ethnocentric thinking when conceptualising authorship.

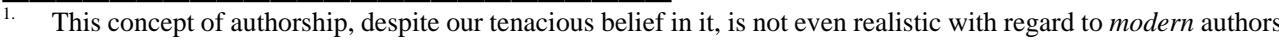
(cf Borsche 1988). See, especially, analyses of the problems of defining and practising copyright: Woodmansee 1984; Jaszi 1991; Price \& Pollack 1992; Rose 1993:1-8. In literary theory, Roland Barthes' 'The death of the author', published in 1968 was a major influence: 'The traditional, humanist concept of a single, human source of all meaning was discarded amid the clamour of disturbances and manifestations against authority all over Europe... With the jettisoning of the Author as the source and gaurantor of all meaning, the path was clear for the proliferation of questions about the process of reading. A revolution in thought had begun' (Biriotti 1993:1).

2. For example, Jerome's and Augustine's fundamental restructurings of the theory of translation (Copeland 1991) and Augustine's working out of a Christian theory of reading (Stock 1996). Or consider the profound impact caused by changes in the function of punctuation which occurred in the fifth and sixth centuries (Parkes 1993) and the crucial intellectual changes associated with the development of word separation (Saenger 1997).

Elizabeth Eisenstein has written a remarkable assessment of the effects of printing on written records (hence on concepts of authorship) and on the shift from one kind of literate culture to another (Eisenstein 1980). 
Foucault's interest in this particular essay is to set up "an introduction to the historical analysis of discourse” (Foucault 1971:117). He considers the 'author as brilliant innovator' a Romanticist invention that had been projected onto history. To do a proper investigation he proposes a distinction between the "socio-historical analysis of the author's persona" ('biography') and the construction of an 'author-function' as an attribute of a text. This author-function represents the social value a text is laden with (or given to) when it is designated as a work of literary creation:

...the author is not an indefinite source of significations which fill a work; the author does not precede the works; he is a certain functional principle by which, in our culture, one limits, excludes, and chooses; in short, by which one impedes the free circulation, the free manipulation, the free composition, and recomposition of fiction (Foucault 1971:118-119).

Thus, for Foucault, the Enlightenment produces a critical turning point in the history of authorship. Writing in this era took on a particular author-function; literature ceased to be understood as simply generally available knowledge and was seen more and more as a unique expression of a single consciousness in each instance.

Foucault also draws attention to another aspect of the systematic attribution of an author-function to texts in the eighteenth century: 'penal appropriation' (1971:108). He suggests the central aspect of Enlightenment authorship to have been censorship: the need for newly emergent states to control transgressive writings by punishing the authors of those writings.

Once a system of ownership for texts came into being, once strict rules concerning author's rights, author-publisher relations, rights of reproduction, and related matters were enacted ... the possibility of transgression attached to the act of writing took on, more and more, the form of an imperative peculiar to literature (Foucault 1971:108).

The process of autonomisation for writers from the need for aristocratic protectors, and the period of professionalisation by means of modern literary property regimes became a system in which writers found themselves isolated before and vulnerable to the monopoly on violence exercised by the modern state, according to Foucault.

The widespread assumption of what authorship constitutes, in terms of property and legislation, namely that it is connected to 'genius', turns out to be a historically determined concept: a result of the limited opportunities for patronage for German-language authors in the eighteenth century who had to promote their texts on the print market (Woodmansee 1994).

Chartier (1994) - in critical dialogue with Foucault - proposes that the major development in the history of authorship during the Enlightenment was that the writer's name, image, and often personality became publicly recognisable. He draws attention to 'the author' appearing for the first time in the late seventeenth century on title pages, frontispieces, and introductory biographies in, especially, editions of collected works. The appearance of these authorial representations suggests that the Enlightenment's new idea of an author was primarily to define a coherent body of work. This process began in the seventeenth century with playwrights, who more than any other type of writer mediated between court, market, and academic institutions. By the end of the eighteenth century the author's name became most important for the new genre of novels, as it specified a work's creativity and originality.

Be that as it may, the historical principle underlying Foucault's short essay is of major importance, namely that authorship is a construction, a historical, cultural and contextual concept. That is, before a proper discussion of the authorship of a specific text can commence, 
we need a 'lexicon of authorship'. Much of this is still wanting with regard to the texts of early Christianity.

\section{Towards a Historical Perspective}

To discuss 'authorship' in antiquity is complex and difficult, for a number of reasons. For instance, the term 'authorship' did not exist in Greek or Latin. Of those who might today be considered 'authors', few if any would have been described by their contemporaries with that rubric. Those who 'wrote' also engaged in various other social and professional practices which were far more important as sources of status, power and social identity.

The Latin term auctoritas (which would eventually evolve into 'auteur') was used in medieval times to refer to the (few) ancient philosophers and their interpreters who could be cited in scholastic argumentation, but in “...the Renaissance humanist vocabulary, auteur began to refer to writers in a different sense, that of creator, and late seventeenth-century dictionaries attributed a second etymology to auteur, of common derivation with artisan, meaning creator” (Brown 2003).

Prior to the Enlightenment, the terminology for what we would think of as authors tended to distinguish according to genres, loosely related to different categories of knowledge or communication, such as poet, rhetorician, storyteller, reporter and such. An entirely different set of terms described those who plied the craft of script and record keeping, including 'writer', 'clerk', 'notary' and 'calligrapher'. It is only by the late seventeenth century that these terms, and the social institutions they describe, became increasingly distant from the world of literary works, and terms such as 'writer' and 'poet' began to describe creators of aesthetically valuable writing (cf Chartier 1994; Hamesse 1999:106-108). ${ }^{3}$

Literary property emerged, as a concept and as a legal practice, during the Enlightenment. ${ }^{4}$ Prior to the eighteenth century, a writer was typically identified with a patron or with the honorific office the writer enjoyed at the discretion of a patron. Since the eighteenth century writers began to establish identities independent from a particular patron (no small reason being the decreasing availability and sufficiency of such patronage). This autonomy claimed by writers could only be established through literary property. Prior to the Enlightenment, "authorial assertions of preeminent domain were all but unthinkable” (Loewenstein 1985:102).

Copyright, as Rose points out, "is not a transcendent moral idea, but a specifically modern formation produced by printing technology, marketplace economics, and the classical liberal culture of possessive individualism” (Rose 1993:142). Certain shifts in worldview, and intellectual developments influenced by thinkers such as Locke, Smith and Kant, generated new, culturally specific ideas of property, labour, individuality and the market. These interacted to justify writers demanding remuneration from and for their writings. Such is the setting for the development of the Continental and Anglo-American notions of copyright,

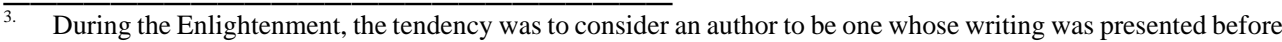
an audience, either orally or in print. It is against the background of the world of gentlemen - the world of dignified, autonomous displays of erudition, taste and intelligence - that we should picture the increasing use of 'author'. That is, claiming to be an author was to change register, to go out on a stage where the public (rather than other 'gentlemen') is the judge of success or failure (cf Brown 2003).

4. That the concept of literary property emerged during the Enlightenment has achieved widespread assent; exactly why and how to explain this appearance has generated considerable debate. See, among many possible references, Darnton 1989; Hesse 1990; Chartier 1997; Rose 1993; Woodmansee 1994; Brown 1999. 
that "charming notion that authors create something from nothing, that works owe their origin to the authors who produce them” (Litman 1990:965).

\section{Aspects of the Greco-Roman Setting for Authorship}

In order to contextualise authorship in the first century we need historical information, to "peer over the shoulders of ancient authors" (Dorandi 1991). This is no mean task; in the following I briefly attend to selected aspects, as a preliminary exploration to contribute to a more comprehensive approach to our texts. These are: the practices of ancient authors, the publication and circulation of books in antiquity, and suggestions for investigating an 'author-function' of a writing.

\section{The writing Phases and Methods of Ancient Authors}

There are only a few reports about the work methods of ancient writers. They are mostly indirect and surprisingly difficult to interpret. The following is a cursory survey of some of the evidence.

A convenient starting point is Pliny the Younger's description of the work methods of his uncle, Pliny the Elder, in his letter to Baebius Macer, who asked for a complete list of Pliny Senior's books (Epistulae 3.5). After listing his uncle’s books, Pliny Junior explains "how such a busy man was able to complete so many volumes". Pliny describes an unusual 'author', one who would even sometimes work halfway through the night - clearly a very exceptional practice which (in part) explains Pliny Senior's productivity. How much we can extrapolate from Pliny's description of his uncle's practices to other writers is therefore a question.

Research began by reading, but reading was done by a reader (lector). In summer Pliny Senior liked to lie in the sun while books were read to him and notes and extracts were made. Making use of every possible opportunity, Pliny had someone read to him during dinners and even at bath time ("while he was being rubbed down and dried"). If he was not being read to, he dictated (audiebat aliquid aut dictabat; Ep 3.5.14). Possibly some notes were made by Pliny himself, but we know that he liked to keep at least one secretary at his side with book and notebook (ad latus notarius cum libro et pugillaribus; 3.5.15).

Lucian of Samosata, in his critique of the sudden rush of petty historians chronicling the Parthian War of 162-165 CE ("not only is everyone writing history, they are all Thucydideses, Herodotuses and Xenophons to us" - Quomodo historia conscribenda sit 2), "offer a little advice" and warning: the writing of history requires effort and a great deal of thought (Hist conscr 5). Towards the end of his tractate, he offers us some ideas of how history writing should proceed:

As to the contents ( pra g mat a a ut a ), he should not collect (s una kt eon) them at random, but only after much laborious and painstaking investigation (a jakrinant a).... When he has assembled (a gr oi s h yeall or most of the facts let him first make them into a set of notes (up o mnhma ), a body of material as yet without charm and unorganised. Then, after arranging them into order (ep iqei $\sim \mathrm{t} h n \mathrm{t}$ axin), let him give it beauty and enhance it with style (l exi ), structure (s c h mat i z et w), and rhythm (Hist Conscr 47-48) 
Despite the apparent familiarity of these activities we should be aware that we do not really know exactly what was meant by several words such as adnoto and excerpta (Pliny) or up omnhma. Or how should we picture these authors collecting material and managing their notes? ${ }^{6}$

However, on the basis of these (and some other references, such as Marcellinus, Vita Thucydidis 47e, and Plutarch's "I read parts of my notebooks") ${ }^{7}$ it is possible to gain some impressions of how Pliny the Elder (probably) and other ancient writers (possibly) carried out their work. Writing a book in antiquity began with a lector ${ }^{8}$ reading a source book(s), of which notes were made, adnotationes - possibly by means of marking the scroll itself , then excerpts were collected and dictated to a notarius (stenographer), who transferred them to pugillares, notebooks consisting of plates made from wood (and wax?), or scrolls of papyrus. From these a text was dictated for writing onto papyrus scrolls (later into a codex made from papyrus or parchment). Alternatively, a further intermediate step took place: an extended collection of notes was made (onto a scroll) from which a draft text was dictated.

Thus, a writer had his sources read to him, marking (adnotare) the places that seemed important for the preparation of his work. Collaborating with (an) assistant(s) he created excerpts and dictated them to a stenographer, who transferred them onto pugillares, or onto a scroll. The result was the first, incomplete version of the work. ${ }^{9}$

We do not know in how many steps an author's work progressed or to what extent further readings and additional research and/or consultations resulted in actual re-workings of the text. We know that more material was noted in the margins of the previously collected parts or it could be added to the verso of the scroll. Various supplementary notes, and linguistic or stylistic improvements found their place either on the margins and on the empty places of the recto or on the verso, but these insertions and additions were not made by the author himself but instead were written down by a scribe or the professional di or qwt $h \forall$ (corrector).

It stands to reason that before the text was copied or dictated for the creation of a good copy in preparation for publication, the collected material could be reworked and rearranged - though how many times and how comprehensively obviously varied from author to author. What is clear is the labour intensiveness (the many hands involved) of 'authoring', and given that, typically, one dealt frugally ${ }^{10}$ with writing materials, extensive and repeated reworking of texts simply was not feasible. Final versions were distinguished from provisional, inter-

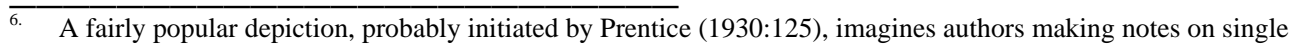
sheets or cards, which were 'kept together in a bundle or in a box'. This, to my mind, is a clear example of anachronistic projection. Dorandi points to the lack of evidence for such a practice; in fact, 'man schrieb auf eine ganze Rolle, nicht etwa auf Einzelblätter' (1991:12). Dorandi cites the informative study by Turner (1983).

7. More precisely, 'I read aloud (a jel exa $m h n$ ) from my note-books (ek $t$ wh up o mnh ma t wn) the observations I have made for my own use’ (Plutarch De tranquillitate animi 464e-465a).

8. In analogy to the a ja g nws $\mathrm{h} \sim$ (slave trained to read, Nepos Atticus 14.1) the lector - typically a slave assumes the role that the author may claim for himself as recitator of his own works, or, if lacking confidence in his own elocution, which he may delegate (Pliny Ep 9,34; Suetonius Divus Claudius 41,2: recitavit per lectorem).

9. An interesting possible confirmation of this process can be found in Herculaneum Papyrus 1021. This scroll contains a first version or scheme of the Academicorum historia by Philodemus of Gadara (philosopher of the Epicurean School, $\pm 110-40$ BCE), i.e., the first, incomplete version of the work as described above (cf Dorandi 1991:16-17). Of course, P Herc 1021 can also be just a collection of pure excerpts. Several papyrus texts containing Philodemus' works were discovered at several locations within a villa in Herculaneum.

10. 'Sparsam' in the words of Blank (1992:82). At issue is not so much the cost of papyrus, discussed in detail by Lewis (1974:129-134), but availability. Writing materials simply was not in over-abundant supply to the extent we are familiar with. 
mediate versions, though the difference often concerned form more than content. It is probable that the second phase could be avoided, or became an alternative (and not just an edited version) to the first. An author could organise the initial versions of his work either by compiling an unstructured conception or a detailed set of notes (up o mnh ma ), either one of which was transferred into the final version (s ug gr a mma or s unt a g ma ). ${ }^{11}$

Other words used for the preparatory stages of writing are exhghsi , succinct explanation, p a r a s keuhy preparatory draft, or up ot up ws i , sketch (cf Van den Hoek 1997:238 n.15). Roughly, then, we can distinguish two phases of authoring an ancient work. The first phase was draft versions based on prior collections of excerpts that had possibly been written on small plates or pugillares. Such provisionary drafts could circulate for review or comments and could even reappear under another name (Blank 1992:118). From these the final version or fair copy of the text (which was called either up omnhma or sumt a gma) was prepared which usually preceded the actual publication (ekdos i ).

Dictation played a dominant role during not just the compilation of the work but also when composing subsequent versions. Indeed, dictation determined all aspects of authoring, including the production of copies for distribution (Skeat 1956). Dorandi (1993) refers to some indications that poets evidently preferred writing themselves, while the prose writers commonly used a system of dictation, perhaps even exclusively. Generalisations are problematic as the evidence involves a wide arena and is tied to many different conditions, methods and personal or subjective circumstances.

Dictation, of course, facilitates an experience of writing as "a public performance, no matter how intimate the recording session and even physical absence of the audience" (Bauman 1986:106).

In the late Republican period and in the early Imperial period a few voices turned against the rampant use of dictation that occurred not only in scholarly works of prose but also in poetry (e.g., Quintilian Inst 1.1.20): dictation, it was felt, when composing, should be regarded with suspicion, as it requires the author's long and careful examination more than writing by one's own hand. Also, young and inexperienced authors may be tempted by dictation to publish careless and largely improvised works. Despite these protestations, dictation determined writing practices until Medieval times (cf Harris 1989:36, 224 n247; Small 1997:171-174, 185).

Depending on his skills and the needs of the author, the secretary recorded the dictation syllable-for-syllable or phrase-by-phrase (i.e. at the speed of writing) or by means of shorthand, at the speed of normal speech. ${ }^{12}$ Often the secretary was entrusted with the responsibility of writing the text from incomplete notes. Authors left considerable scope to their secretaries; either on purpose, or due to rapid dictation, or because often only an outline or draft was provided. The line between editing and co-authorship is impossible to draw.

If one writer excerpts or copies portions of another's work, but adds comments, supplements, appendices or insertions - or subtracts or epitomizes - then whether we regard the

$\overline{11 .}-\overline{\text { Again, if }} \overline{\text { we }} \overline{\mathrm{follow}} \overline{\mathrm{D}} \overline{\mathrm{oran}} \overline{\mathrm{di}} \overline{(199} \overline{1: 26}-\overline{29})$, something of this process can be substantiated from an analysis of the colophons of several papyri from Herculaneum (P Hercul 1427, 1506 and 1674), which contain books of rhetoric by Philodemus. Dorandi distinguishes between up o mnh ma and up omnh ma $\mathrm{i}$ k on, with the latter indicating a more preparatory and less definitive stage of the redaction of the text than the former.

12. Dictation syllabitim is self-evident. See, e.g. Seneca Epistulae 40.10. Dictation viva voce supposes shorthand systems and the use of a t a c ugr a f $0 \sim$ (cf LSJ); see Seneca Epistulae 40.25; Suetonius Divus Titus 3.2. It was possible for a secretary to record a speech in the Roman senate (Seneca Apocolocyntosis 9.2). Cf Sherwin-White 1966:225. 
'new' work thus produced as distinctively a different document in its own right, or as a 'new edition’ or adaptation of the old, becomes a matter of degree only (Hall 1996:412-413).

\section{Publication}

The relationship between author, written language and 'reader/reading public' is not at all self-evident, especially where the concept of personal authorship had little association with property and individual, introspective identity. In antiquity books were often published without the name of the author or under another person's name. Works were collective, traditional, cultural enterprises.

Indeed, the very term 'publication' is not quite appropriate to translate ekdos i , which is (mostly) used to indicate the making public of a work by means of an oral presentation of the text (Hadas 1954:60-64; Harris 1989:224-225). It is self-evident that such an act included a wide range of activities.

Often, 'publication' would be initiated by a dedication. The dedication of a literary work is the naming of a person with the intent of expressing an honour or gratitude to this person by association with the writing. Modern practice places the dedication as part of the so-called paratext (that is, on the title page, or on book covers, or in prefaces), but Greek and Latin dedications preserved from antiquity are part of the actual work. ${ }^{13}$ The basic form of the dedication is an address at the opening of the text, as we find in Cicero when speaking of his literary plans in his letters to Atticus, or at some convenient point in the main part of the text (cf Janson 1964:105-106, 116-124).

The use of dedications in Hellenistic and Roman literature is related to the patron-client system so characteristic of Greco-Roman times. The recipients of a dedication may be rulers (Ovid Fasti 2.11-18 = to Caesar Augustus), ${ }^{14}$ members of the ruling house (Ovid Fasti 1.3-26 = Germanicus, son of Drusus, brother of Tiberius), politically powerful persons, known as patrons of poetry, such as Maecenas, Octavian's right hand man and patron of Vergil (Georgics 1.1-5); or Messala, patron of Tibullus (2.1.31-35). ${ }^{15}$ Often they are highly ranked friends (Statius Silvae 1 praef) It is evident from statements in Cicero's letters that reciprocal dedications were an important means of group contact in literary circles. Plutarch dedicated several of his treatises to friends, undoubtedly to maintain his associations. Often the recipient is a protector or patron of the author (Baldwin 1982; Williams 1982). An author also gained prestige through dedication to high-ranking individuals.

A dedication copy is obviously presented or sent to the receiver, which is (in a sense) a public ritual. How dedication and publication relate to each other cannot be stated with certainty. Sometimes publication is made dependent on the recipient's approval. This obviously relates to the fairly common practice of an author circulating his work among friends and requesting criticism before publication. These circles of friends were also the primary audience addressed by an author - only after discussions there he would present his works to a

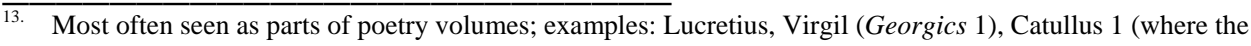
dedicatory poem introduces the body of the poetry book).

14. Valerius Maximus Factorum et dictorum memorabilium praef is a dedication to Tiberius. Valerius is the earliest extant prose author to invoke the emperor (Wardle 1998:68).

15. About the aristocrat M. Valerius Messalla Corvinus: Maltby 2002:41-42. 
wider audience in public readings or sometimes even dramatic performances, thereby publishing them. ${ }^{16}$ Authors sometimes carefully planned the timing of making a work public.

As for the time when he published (ejedwken)his dialogues, this was not left to chance, but he chose holy-days and festivals of the gods for his works to be offered up and made known to the public (khrutt wnt ai)... Thus he published (ejedwken) the Timaeus at the Bendidia..., the Parmenides at the Panathenaea, and others at other festivals (Anonyma prolegomena in Platonis philosophiam 16.35). ${ }^{17}$

The author could either promote his work himself or entrust it to a publisher who arranged for copies, assuming the production costs (in some cases with financial assistance from the author or his patron), and taking care of the distribution. The most famous publisher in antiquity was probably Atticus, a friend of Cicero's. In his workshops, Atticus employed a number of highly qualified scribes (librarii) and proof-readers (anagnostae), whose service helped him to issue high-quality publications. In some cases, the author himself or a scholar could examine the copies, a practice which often led to changes in content.

The 'performative readings' of texts in the Roman era is crucial to understanding literary activity. The recitatio was, by and large, the medium through which an author's work came to be experienced by others. Pliny (Ep 1.13) writes that in April one could hardly have a day go by without someone giving a public reading - he also praises "those whose interest in writing and reading aloud is not dampened by the idleness and conceit of their listeners".

The author could do the recitation himself, but often a lector was engaged. In a letter written to Suetonius, asking advice about his poor reading skills, Pliny explains:

I am told that I read badly - I mean when I read verse, for I can manage speeches, though this seems to make my verse reading all the worse! So, as I am planning to give an informal reading to my personal friends, I am thinking of making use of one of my freedmen. This is certainly treating them informally, as the man I have chosen is not really a good reader, but I think he will do better than I can as long as he is not nervous... Now, I don't know what I am to do myself while he is reading, whether I am to sit still and silent like a mere spectator, or do as some people and accompany his words with lips, eye, and gesture (Epistulae 9.34).

The impact of this practice was extensive on how an author composed, structured and styled his work. Surely this must have been a contributing factor in the so-called increasing rhetoricisation of Roman literature during the Empire.

Recitatio also helps to understand the relative lack of punctuation in texts from Greco-Roman antiquity. Prior to the fifth and sixth centuries texts had been written largely free of punctuation or word separation in keeping with the expectations of readers trained in the art of Roman rhetoric. "Writing, for them, was to be in the most neutral form possible, since it was the responsibility of the reader, declaiming aloud, to divine the rhythms of the cursus which signalled the formulaic clausulae marking the major divisions, or cola and periodi, of the discourse” (Briggs 2000:412-413).

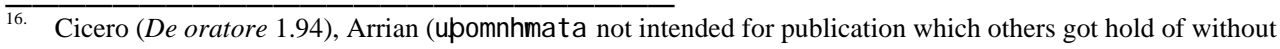
his will or knowledge, Epicteti dissertationes 1 dedicatio 2-4) and Tertullian (Adversus Marcionem 1) all refer to this distinction between private/limited circulation and regular publication, and its attendant problems.

17. Westerink 1962:32, 33. The Prolegomena was a handbook introducing Plato in the Alexandrian School. The point is not about Plato's methods, but that this is how a teacher of Late Antiquity thought an important author operated. 


\section{Circulation of Books}

After the book was copied the task of distribution was seen to by the publisher who sometimes was also the bookseller. However, given that publication in antiquity consisted of an oral presentation of the particular text, "the primary way of distributing books was not ... by means of a trade of any kind, but through gifts and loans among friends" (Harris 1989:225). The forces of social status that regulate such relationships (Starr 1987:213) must have been shaping forces for an author's work as well. Most readers depended largely, if not exclusively, on privately made copies of texts, without the substantial intervention of any commercial system of distribution (Starr 1987:215-216). Bear in mind, that this was a world where one had no guarantee that a work was even by its putative author. In a world of copying, forgeries, and formula, the notions of originality and intellectual property were unknown (Troll 1990:103). ${ }^{18}$

Book dealers were, in Starr's words (1987:220), the owners of small shops that dealt in luxury items, apparently only handling current literature and not selling older works. It is important to keep in mind the underlying dynamics of ancient book circulation: literature was a symbol of social status (and conversely, a point of access to the upper class, a way of making contact with the elite), and remained the preserve of the aristocracy except in oratorical events and public performances (cf Starr 1987:223).

\section{The 'viva vox' as author-function}

A discussion of possible author-functions of texts from the Roman Period will need to investigate how the emergence of the Principate affected the relationship between literature and politics, specifically the various positions of an author within the Roman state with its increasingly monarchist structures. This would require detail as well as general trends, and must cover the entire range from panegyrics to fundamental opposition.

In addition to these socio-political aspects of writing several other salient aspects should also come into purview. For example, various works reveal authors' struggle to establish their identity or polemically dealing with their traditions in literary-historical self-reflection (cf Schmitzer 2002).

Another challenge would be to understand the role of biographical information for the interpretation of texts according to the ancients. A number of indications make it quite clear that the biography of an author was considered important to ancient readers /exegetes: the bios of an author should be studied and known before one starts with his writings (Mansfeld 1994: passim). Despite this focus, the concept of an artistic oeuvre as an entity was unknown in antiquity; a publication "was not seen as the conclusion of a productive process, and thus third parties principally had no scruples interfering with an author's work - e.g. by interpolation or even to attribute other works to him in order to profit from the reputation of a famous name” (Schmitzer 2008). What is noteworthy is that the role of such biographical

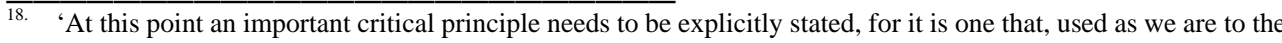
printed word as a primary vehicle of communication, with its attendant apparatus of publishing houses and copyright law (and, in scrupulous scholarship, careful observance of distinctions between exact quotation, paraphrase and referential citation), we too easily overlook. Where all documentary communication is hand written, as for any ancient writer it was, the distinctions that appear clear to us between author and scribe, copyist and commentator, editor, secretary, "literary executor", and publisher, lose much of their significance' (Hall 1996:412).
} 
'information' was not historical as we would understand it. Often, it seems, the bios of the author - in the sense of the help it offers for understanding what he wrote - lies in its prescriptive implications, like the wise man striving to be useful even after his death (to adapt Seneca Epistulae morales 102.30).

The self-statements by various authors can and should also be investigated. However, to conclude this list of possibilities I want to draw attention to the viva vox.

The Mediterranean world of Roman times is often described as 'face-to-face' communities (Brown 1978:3; Malina 2001:88-91). This 'face-to-face' setting is the pre-condition for any attempts at formulating possible author-functions of ancient texts. Reading in antiquity was not experienced as a silent scanning, mainly mental activity. It was a performative, vocal, oral-aural event (Dorandi 1993:81; Botha 2005:622-625). Reading aloud while others listened is a practice that cements sociability, adding distinct elements to the social functions of writing and publishing. It is printed matter that first, in the history of books, made it possible for an author to reach right into the heart of the single individual, and it is only the mass-produced printed book that can be an object imbued with moments of private life, a memory or an emotion or some sign of identity.

The Greco-Roman emphasis on the living voice is well-known (Botha 1993). Yet, it is precisely this emphasis in the context of writing that - I propose - reveals something about textualised authors. A text, words written, the implied author, was meant to become a living voice.

\section{Towards a Cultural-historical Understanding of Authorship}

To make some progress towards historically conceptualising authorship and towards contextualising the author-function in Roman times some imperatives seem appropriate.

- Firstly, a distancing, self-critical move is necessary. Projecting the problematic nature of modern notions of authorship onto authors from antiquity is to underestimate the historical and cultural determinedness of communication. Writing is never merely writing; it is part of a communicative event, inscribed into a cultural pattern or system (Olson 1988:27). We need to be aware of the complexities of ancient literacy, orality, tradition and communication, and active steps towards this critical awareness should become part of our scholarship.

The 'author' is a construct; ${ }^{19}$ hence the requirement of a self-critical look at our understanding of authorship. Foucault (1971:101) has indicated the issues at stake when he observed that it would be worth examining "how the author became individualized in a culture like ours, what status [the author] has been given, at what moment studies of authenticity and attribution began, in what kind of system of valorization the author was involved, at what point we began to recount the lives of authors rather than of heroes, and how this fundamental category of "the-man-and-his-work criticism” began”. Foucault's questions go to the heart of the problem that is the concern of this article; prompting us, when we study early Christian texts, to consider, "What are the modes of existence of this discourse ? ... Who can assume these various subject functions? ... What difference does it make who is speaking?” (Foucault 1971:120).

$\overline{19}$. This claim is, primarily, in terms of $\overline{\text { discourse }} \overline{\text { and }} \overline{\text { not }} \overline{-}$ subjectivity. The concern is with the representation of authorship and notions of property, originality, influence and authority. See also Saunders \& Hunter’s (1991) critique of treatments of authorship that are, in their words, 'subject-centered'. 
- Secondly, detailed consideration of the 'substance' of authoring is imperative when discussing contexts of our texts. The material aspects and the communal interactivity of writing (and reading) in Roman times can no longer be neglected. An 'author' was essentially a craftsman; basically he was master of a body of rules, preserved and handed down to him in rhetoric and poetics, for manipulating traditional materials in order to achieve the effects prescribed by the patron (and) or audience to which he owed both his livelihood and social status.

- Thirdly, always to keep in mind that to practice his craft an author required a group effort. This wider circle of readers, assistants and secretaries determined the product, its dissemination and, necessarily, had various effects on loyalties in its creation. Research and reflection were by means of recitation and listening; composition by means of dictation.

Das Verfassen des Textes, das, wenn es autographisch war, von dem Geräusch der Stimme begleitet wurde, oder das Verfassen vermittels des Diktats oder auch die Probelektüre des Textes, die der Autor Freunden gab, waren zweckdienlich für eine Schrift, die in der Hauptsache zum Hören gedacht war. ${ }^{20}$

Given the 'communal', interactive authorship of ancient documents, a number of typical exegetical interests of modern biblical scholarship require careful reconsideration. Authorship/author (as category of interpretation) is considered as central to our discipline not only in theory, but in practice: in the way single-figure studies dominate criticism; in the organisation of texts in 'editions'; in biographical studies; and above all, in the idea of 'style', of a writing marked uniquely and characteristically, a style expressing a person's 'mind' or 'psyche' whose essential identity scrawls across a page and declares its supposed 'ownership' of self-revealing and self-constituting discourse. Historicising authorship must dramatically impact on this particular paradigm of scholarship.

- Fourthly, a new appreciation for the importance of 'micro-history', of the concretising of social history (cf Magnússon 2003) seems relevant.

Reading is a 'way of taking meaning from texts'. 'Ways of taking' from books are "as much a part of learned behaviour as are ways of eating, sitting, playing games and building houses” (Heath 1982:49). Consequently the literacy events in which people participate and the meanings they 'take' from them require a broad framework of socio-cultural analysis in order for ancient reading and writing to make sense (cf Heath 1982:74). It is in this sense that the importance of the history of the everyday becomes crucial.

To gain an understanding of the process of authoring and the writing of books in antiquity we clearly need the perspective of communication-as-performance theories, but they must be based on a history of everyday life, informed by the routines, habits, and phenomena associated with writing and reading in those times. To find ancient 'author-functions' we need to reconsider everyday life as sites of cultural creativity. It is in the habits, rituals, routines, and traditions of daily life that meaningful communication was embedded, and writing and reading were pertinent occasions for and ways of associating with others, unique to the poleis and smaller communities of the Roman empire.

- Fifthly, the role of patronage when construing ancient authorship can hardly be overestimated.

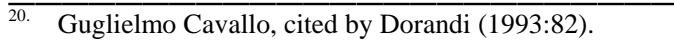




\section{Concluding Remarks}

In conclusion, I summarise the gist of the argument presented here by means of some propositions, inviting further discussion and research.

- Although socio-cultural history has become prominent in NT scholarship, crucial topics are still neglected. Many investigations of early Christian texts operate with a very inadequate model of authorship. We need to avoid anachronistic terminology and conceptualisations and uncritical ethnocentrism when it comes to authorship, literacy, tradition, writings and other aspects of ancient communication. Romantic conceptions of authorship are inappropriate in discussing the cultural productions of antiquity.

- A lot about earliest Christianity, given current evidence, cannot be known. We should be willing critics committed to discrediting problematic claims and longstanding myths, even at the cost of an apparent reduction in historical knowledge.

- Authorship should be studied as a sociological and cultural problem, and analysed with the aid of cross-cultural models.

- The history of the book is as relevant and as important to our disciplines as the history of the Roman Empire. Much of biblical scholarship has been practised as if that history had no importance for the comprehension of works. It is precisely the history of the book that can inform us about the techniques, practices and expectations of those who produced the texts studied in NT scholarship.

- Our practice and experience of authorship are determined by distinct values relating to literary property and censorship; authorship to us is inextricably linked to income, and due to the printing revolution our understanding thereof has become fundamentally visual. In earlier times, authorship was intimately part of patronage and mainly understood in aural, performative terms.

- We should be conscious of the (vast) differences between the notions of the creative individual and intellectual property underlying contemporary notions of authorship, and the fact that most literary work in antiquity was corporate rather than individual. Furthermore, many of the written products of antiquity tend to be formulaic.

- The 'living voice' played a major, if not the predominant role during the compilation of the work, in its production and its being made public, as well as in the exegesis and use of a work.

- Questions about authorship are about the relationship between author, written language and 'reader/reading public'. The associations of personal authorship had unique meanings in antiquity. Books could be (and were) published without the name of the author or under another person's name. Literary works were collective undertakings. Individuals associated with texts related to authority (and not to origins).

- The study of writing and authoring practices reveals not only an oral-aural communicative experience but also, and then vividly, the social inequalities and hierarchies determinative of the Greco-Roman world.

- Where all documentary communication is handwritten, as for any ancient writer it was, the distinctions that appear clear to us between author and scribe, copyist and commentator, editor, secretary, student, plagiarist and publisher, lose much of their significance. 


\section{BIBLIOGRAPHY}

Baldwin, B 1982. Literature and society in the later Roman empire, in BK Gold ( ed.), Literary and artistic patronage in ancient Rome, 67-83. Austin: University of Texas Press.

Bauman, R 1986. Story, performance, and event: Contextual studies of oral narrative. Cambridge: University Press.

Biriotti, M 1993. Introduction: Authorship, authority, authorisation, in M Biriotti \& N Miller (eds.), What is an author?, 1-16. Manchester: Manchester University Press.

Blank, H 1992. Das Buch in der Antike. München: Beck.

Borsche, T 1988. Wer spricht, wenn wir sprechen? Überlegungen zum Problem der Autorschaft. Allgemeine Zeitschrift für Philosophie 13(3), 37-50.

Botha, PJJ 1993. Living voice and lifeless letters: Reserve towards writing in the Greco-Roman world. Hervormde Teologiese Studies 49, 742-759.

Botha, PJJ 2005. New Testament texts in the context of reading practices of the Roman Period: The role of memory and performance. Scriptura 90, 621-640.

Briggs, CF 2000. Literacy, reading and writing in the medieval West. Journal of Medieval History 26(4), 397-420.

Brown, GS 1999. After the fall: The “Chute” of a play, "Droits d'auteur”, and literary property in the Old Regime. French Historical Studies 22(4), 465-491.

Brown, GS 2003. Authorship, in AC Kors ( ed.), Encyclopedia of the Enlightenment. Oxford: Oxford University Press. (http://0-www.oxfordreference.com < retrieved 23 November 2007>).

Brown, P 1978. The making of late antiquity. Cambridge (Mass.): Harvard University Press.

Chartier, R 1994. Figures of the author, in The order of books: Readers, authors and libraries in Europe between the fourteenth and eighteenth centuries, 25-60. Oxford: Polity Press.

Chartier, R 1997. The man of letters, in Y Vovelle ( ed.), Enlightenment portraits, 142-189. Chicago: Chicago University Press (Original publication 1992).

Copeland, R 1991. Rhetoric, hermeneutics and translation in the Middle Ages: Academic traditions and vernacular texts. Cambridge: Cambridge University Press.

Darnton, R 1989. The facts of literary life in pre-revolutionary France, in YM Baker (ed.), The political culture of the Old Regime, 261-291. Oxford: Oxford University Press.

Dorandi, T 1991. Den Autoren über die Schulter geschaut: Arbeitsweise und Autographie bei den antiken Schriftstellern. Zeitschrift für Papyrologie und Epigraphik 87, 11-33.

Dorandi, T 1993. Zwischen Autographie und Diktat: Momente der Textualität in der antiken Welt, in W Kullmann \& J Althoff (eds.), Vermittlung und Tradierung von Wissen in der griechischen Kultur, 71-83. ScriptOralia, vol. 61. Tübingen: Gunter Narr Verlag.

Eisenstein, EL 1980. The printing press as an agent of change: Communications and cultural transformations in early-modern Europe. Cambridge: Cambridge University Press.

Foucault, M 1984. What is an author? In P Rabinow ( ed.), The Foucault reader, 101-120. London: Penguin. (Original work published 1971).

Hadas, M 1954. Ancilla to classical reading. New York: Columbia University Press.

Hall, LGH 1996. Hirtius and the Bellum Alexandrinum. Classical Quarterly 46(2), 411-415. 
Hamesse, J 1999. The Scholastic model of reading, in G Cavallo \& R Chartier (eds.), A history of reading in the West, 103-119. Oxford: Polity Press.

Harris, WV 1989. Ancient literacy. Cambridge (Mass.): Harvard University Press.

Heath, SB 1982. What no bedtime story means: Narrative skills at home and school. Language in Society 11, 49-76.

Hesse, C 1990. Enlightenment epistemologies and the laws of authorship in revolutionary France, 1777-1793. Representations 30, 114-116.

Janson, T 1964. Latin prose prefaces: Studies in literary convention. Stockholm: Almqvist \& Wiksell.

Jaszi, P 1991. Toward a theory of copyright: The metamorphoses of “authorship”. Duke Law Journal 1991(2), 455-502.

Lewis, N 1974. Papyrus in classical antiquity. Oxford: Clarendon.

Litman, J 1990. The public domain. Emory Law Journal 39(4), 965-1023.

Loewenstein, J 1985. The script in the marketplace. Representations 12, 101-114.

Mack, BL 1988. A myth of innocence: Mark and Christian origins. Philadelphia: Fortress Press.

Magnússon, SG 2003. The singularization of history: Social and microhistory within the postmodern state of knowledge. Journal of Social History 36(3), 701-735.

Malina, BJ 2001. The social gospel of Jesus: The kingdom of God in Mediterranean perspective. Minneapolis: Fortress.

Maltby, R 2002. Tibullus: Elegies. Text, introduction and commentary. Cambridge: Francis Cairns.

Mansfeld, J 1994. Prolegomena: Questions to be settled before the study of an author, or a text. Philosophia Antiqua, vol. 61. Leiden: Brill.

Olson, DR 1988. Mind and media: The epistemic functions of literacy. Journal of Communication 38(3), 27-36.

Parkes, MB 1993. Pause and effect: An introduction to the history of punctuation in the West. Berkeley: University of California Press.

Piñero, A, \& Peláez, J 2003. The study of the New Testament: A comprehensive introduction. (DE Orton \& P Ellingworth, Trans.). Leiden: Deo Publishing.

Prentice, W K 1930. How Thucydides wrote his history. Classical Philology 25(2), 117-127.

Price, ME., \& Pollack, M 1992. The author in copyright: Notes for the literary critic. Cardozo Arts and Entertainment Law Journal 10(2), 703-720.

Rose, M 1993. Authors and owners: The invention of copyright. Cambridge, MA: Harvard University Press.

Saenger, PH 1997. Space between words: The origins of silent reading. Stanford: Stanford University Press.

Saunders, D., \& Hunter, I 1991. Lessons from the "literatory": How to historicise authorship. Critical Inquiry 17, 479-509.

Schmitzer, U 2002. Die Macht über die Imagination: Literatur und Politik unter den Bedingungen des frühen Prinzipats. Rheinisches Museum für Philologie 145, 113-135. 
Schmitzer, U 2008. Authors: Classical antiquity, in H Cancik \& H Schneider (eds.), Brill's New Pauly: Antiquity volumes. Brill Online. (http://0-www.brillonline.nl < retrieved 30/04/2008>).

Sherwin-White, AN 1966. The Letters of Pliny: A historical and social commentary. Oxford: Clarendon Press.

Skeat, TC 1956. The use of dictation in ancient book-production. Proceedings of the British Academy 42, 179-208.

Small, JP 1997. Wax tablets of the mind: Cognitive studies of memory and literacy in classical antiquity. London: Routledge.

Starr, RJ 1987. The circulation of literary texts in the Roman world. Classical Quarterly 37, 213-223.

Stock, B 1996. Augustine the reader: Meditation, self-knowledge, and the ethics of interpretation. Cambridge (M): Harvard University Press.

Troll, DA 1990. The illiterate mode of written communication: The work of the medieval scribe, in RL Enos ( ed.), Oral and written communication: Historical approaches, 96-125. Newbury Park: Sage Publications.

Turner, EG 1983. Sniffing glue. Cronache Ercolanesi 13, 7-14.

Van den Hoek, A 1997. The "catechetical” school of early Christian Alexandria and its Philonic heritage. Harvard Theological Review 90(1), 59-88.

Wardle, D 1998. Valerius Maximus Memorable deeds and sayings, Book 1: Translated with introduction and commentary. Oxford: Clarendon.

Westerink, LG 1962. “Anonymous prolegomena to Platonic philosophy”: Introduction, text, translation and indices. Amsterdam: North-Holland Publishing.

Williams, G 1982. Phases in political patronage of literature in Rome, in BK Gold ( ed.), Literary and artistic patronage in ancient Rome, 3-27. Austin: University of Texas Press.

Woodmansee, M 1984. The genius and the copyright: Economic and legal conditions of the emergence of the “author”. Eighteenth-Century Studies 17(4), 425-448.

Woodmansee, M 1994. The author, art, and the market: Rereading the history of aesthetics. New York: Columbia University Press. 